UJBM, Vol. 4, No. 7, January - June 2005, pp 40-68

ISSN 0975-3311 | https://doi.org/10.12725/ujbm.5.6

\title{
ENTREPRENEURIAL SURVEY IN RELATION TO COMMERCIAL BANKS' LENDING
}

\section{Anitha H.S.*}

Entrepreneurship in India, even today, is the prerogative of certain sections of the society. These classes are the major beneficiaries of entrepreneurial schemes and programmes of the government and financial institutions. It has been proved time and again that those who have come from trade and industrial backgrounds get easy access to non-institutional finance, but those who have come from a professional background mainly depend on institutional finance. Sadhak found that entrepreneurs who were formerly traders had better access to financial resources than fechnocrat/professional entrepreneurs. Manohar V. Deshpande found that the institutional agencies such as IDBI, SFCs and commercial banks, created by the government to help prospective entrepreneurs were not successful in developing entrepreneurs from all castes in the Marathwada region of Maharashtra state.

\section{Social Profile of Entrepreneurs}

The emergence of an entrepreneur is conditioned by socio-cultural economic variables. Pareek and Nadakarni observed that the four factors influencing entrepreneurial growth are the individual, socio-cultural traditions, the support system and the environment. For the successful emergence of any entrepreneurs,

* Department of Commerce, Kuvempu University, P.G. Centre, Davangere 
these variables play a greater role. In a study conducted by Krishnalal Sharma and Singh, it was found that the caste and family background of entrepreneurs had a significant influence on them. They also found that government facilities are enjoyed largely by people with a business background. In a study of 125 entrepreneurs in Kolhapur, S.G. Bhanushali found that caste, education and parental occupations had a greater impact on attaining higher degrees of entrepreneurial success.

The success of any entrepreneurship, as history shows, changes from area to area, community to community and people to people. For example, the Tatas, Birlas and Ambanees (all from the Parsee community) in heavy industries, the Shettys from Andhra Pradesh in the gold and jewellery business, the Bhant/Shets of Dakshina Kannada district in the hotel business (Non-vegetarian) and Kamath and Udupi Brahmins in the hotel business (Indian cuisine only).

This paper is built on the primary data collected during the field survey carried out while executing a UGC sponsored Major Research Project on 'Role of Commercial Banks in financing and promoting small entrepreneurs in Karnataka'. This paper focuses on the social profile of entrepreneurs.

It is in the light of the above analysis, that the study of the social background of entrepreneurs assumes importance. The knowledge of socio-economic factors is therefore, of great help in formulating future policies regarding schemes of financial assistance, concessions, subsidies etc. In order to ascertain the type of people who have taken to entrepreneurship in the state, biological and social factors such as age, educational backgrounds, category of entrepreneurs, family background, the relationship among these factors and the factors which motivate them to become entrepreneurs have been considered. The study has revealed the following:

\section{Age of Entrepreneurs}

Data collected from the entrepreneurs being studied revealed that almost an equal number of entrepreneurs have hailed from 3 different age groups as indicated in. To elucidate, 43 entrepreneurs constituting $35.84 \%$ were over 45 years of age, 39 entrepreneurs constituting $32.50 \%$ were in the age group of $35-45$ years and 38 entrepreneurs constituting $31.66 \%$ were less than 35 years of age. It was found that all the entrepreneurs surveyed were married. Table 1 shows the age group-wise distribution of entrepreneurs. 
Table 1. Age of Entrepreneurs

\begin{tabular}{l|c|c}
\hline Age (years) & Marital Status & Percentage \\
\hline Less than 35 & 38 & 31.66 \\
$36-45$ & 39 & 32.50 \\
Above 45 & 43 & 35.84 \\
\hline Total & 120 & 100.00 \\
\hline
\end{tabular}

Source: Survey Data

\section{Educational Level of Entrepreneurs}

Some amount of education/worldly knowledge has always been considered as an important asset of an individual in building his occupational career in a bureaucratic sociefy. It is said in the Rigveda that knowledge is power. It helps him not only in the acquisition of the required skills for a job demanding non-traditional skills but also in imparting knowledge about different occupational opportunities. In an underdeveloped economy education is always looked upon as a means to improve one's socio-economic position in society. Now, doubts are being expressed about the effect of formal education on entrepreneurial supply. This is because in an underdeveloped country, the educated are likely to take up positions in the bureaucracy as it commands more respect in society and also generates an assured income. The present trend among educated youth in India is an illustration to this. It is also possible that entrepreneurs with higher levels of education may have chosen entrepreneurial pursuits because of their failure in getting government jobs.

Several studies on entrepreneurship have examined the relationship between the level of education and entrepreneurial growth. A.S. Rao, in a study of chemical industries in Baroda city, found that the firms owned by graduates and entrepreneurs with technical backgrounds were better off than other firms. Oamen has attributed the lesser proportion of entrepreneurs in the Kerala state to the inadequacy of education and technical knowledge.

An examination of the level of education of a sample of entrepreneurs indicates that (Table 2) $43.33 \%$ of the entrepreneurs had a technical education background, $25 \%$ had collegiate level education, $22.50 \%$ had obtained primary education and only $9.17 \%$ had obtained education upto matriculation. Thus, a total of $68.33 \%$ of the entrepreneurs under study had obtained collegiate education (which includes technical education). 
Table 2 shows the education level of entrepreneurs under study in Karnataka state.

Table 2. Level of Education of Entrepreneurs

\begin{tabular}{l|c|c}
\hline Level of Education & No. of Entrepreneurs & Percentage \\
\hline Primary Education & 27 & 22.50 \\
Matriculation & 11 & 9.17 \\
Collegiate Education' $^{\prime}$ & 30 & 25.00 \\
Technical Education' & 52 & 43.33 \\
\hline Total & 120 & 100.00 \\
\hline
\end{tabular}

1. Entrepreneurs with PUC, General degree and Post-Graduation

2. Entrepreneurs with Engineering, Diploma, ITI, B.Pharma, B.Arch and Medical Education Source: Survey Data

\section{Category-wise Distribution of Entrepreneurs}

The background of any community and its business acumen have their own influence on its entrepreneurial supply. This has been observed by Everett in Japan, the Former Soviet Union and Latin America. In most countries, entrepreneurs have emerged from a particular socio-economic class.

In India, industrial entrepreneurship has often been analysed in terms of the entrepreneurs community and the pursuits associated with the community. The community system has been found to be exercising its own impact on occupational mobility. Some communities like the Parsees, Marwarees and Sindhees seem to have an inclination towards industrial activity. However, it is true that certain communities have imbibed a spirit of entrepreneurship. Hence, the community factor should invariably be examined while studying entrepreneurship.

Table 3 shows the category-wise distribution of the entrepreneurs under the study.

Table 3. Category-wise Distribution of Entrepreneurs

\begin{tabular}{l|c|c}
\hline \multicolumn{1}{c|}{ Community } & No. of Entrepreneurs & Percentage \\
\hline Schedule Caste and Tribe & 7 & 5.83 \\
Women Entrepreneurs & 10 & 8.33 \\
Minority Community & 6 & 5.00 \\
Backward Community & 24 & 20.00 \\
General Category & 73 & 60.84 \\
\hline Total & 120 & 100.00 \\
\hline
\end{tabular}

Source: Survey Data 
It may be seen from Table 3 that $60.84 \%$ of entrepreneurs in the study area hail from the general category. The entrepreneurs belonging to the backward community $(20 \%)$, women entrepreneurs $(8.33 \%)$, schedule caste and tribes $(5.83 \%)$ and the minority community $(5 \%)$. The entrepreneurs rank second, third, fourth and fifth respectively. The above figures depict that banks are still lagging in attracting the neglected class of the Indian society i.e., SC/ST, women and minorities, to the entrepreneurial field.

\section{Family Background of Entrepreneurs}

The influence of family background on the emergence of entrepreneurs has been documented by several research studies. A study conducted by Manohar V. Deshpande revealed that caste, family occupation and father's occupational status are important for entry into the business of manufacturing. But, several studies have revealed that entrepreneurs are increasingly emerging from diverse social groups.

In view of the above, the family background of the entrepreneurs under the study have been examined in Table 4 below.

Table 4. Family Background of Entrepreneurs

\begin{tabular}{l|c|c}
\hline Family Background & No. of Entrepreneurs & Percentage \\
\hline Trade or industrial background & 50 & 41.66 \\
Agricultural background & 27 & 22.50 \\
Service/Employment background & 43 & 35.84 \\
\hline Total & 120 & 100.00 \\
\hline
\end{tabular}

Source: Survey Data

Table 4 reveals that, a trade or industrial background was the family background of the highest number of entrepreneurs ( $41.66 \%$ ) followed by a service or employment background (35.84\%) and as agricultural background (22.50\%).

These figures show the bagging of commercial banks' resources entrepreneurs with a trade or industrial background and their continued dominance of the entrepreneurial field.

\section{Factors Motivating an Entrepreneur}

The entrepreneurs under study were asked to rank the various factors which motivated them to become entrepreneurs. Since man is a product of his own environment, the prevailing socio-economic, psychological and cultural factors naturally influence 
him and act as a source of inspiration to become an entrepreneur. As such it is the ambition or aspirations, compelling factors and facilitating factors that make an entrepreneur.

Ambitions or aspirations motivate men, activise them, broaden their vision and make their lives meaningful. Various ambitions which motivate a person to become an entrepreneur are the desire to achieve something in life, fulfill need for independence, get gainfully occupied, gain social prestige, continuing family businesses, etc. S. Ashok Kumar, in his study on entrepreneurship in small industries in two industrial estates of Andhra Padesh, found that the ambition of becoming self reliant was ranked first and the ambition of giving shape to their ideas and skills received second rank. To make money, to continue the family business and to gain social prestige and power are the other influencing factors.

However, many a times it is the compulsion rather than the ambition that leads men to success. Sometimes initial ambition and opportunities may clash with each other. Then the closing destiny is shaped by the compulsion of the situation. In a study of entrepreneurship in two industrial estates of Andhra Pradesh, Ashok Kumar found that 10 out of 20 entrepreneurs were compelled by dissatisfaction with previous jobs and unemployment.

Ambitions or compulsion alone may not make an entrepreneur. At times, the encouragement of family members, friends and relatives, the experience gained in employment, the skill acquired or inherited, availability of finance from banks and financial institutions, subsidies and concessions given by the government, success of others etc., also facilitate the exercise of entrepreneurship. In a study on the entrepreneurial process and promises conducted by BEWN Murthy and others in Andhra Pradesh, it was found that previous association in the same or other line of activity, success stories of entrepreneurs and advice or influence of family members/ friends/relatives, facilitated entrepreneurship.

In the present study, the entrepreneurs surveyed were asked to rank the different factors, which motivated them to become entrepreneurs in their order of importance (Listed in Table 5). The factors indicated by them were rated by a weighted score according 3 points to the factors ranked first, 2 points to the factor ranked second and one point to the factor ranked third/last. The factors which influenced entrepreneurs in the study area have been shown in Table 5. 
Table 5. Factors Motivating Entrepreneurs

\begin{tabular}{|c|c|c|c|c|c|c|c|c|}
\hline Motivating Factors & $\begin{array}{c}\text { No. of } \\
\text { Ent. } \\
\text { opted } \\
\text { for } 1^{\text {st }} \\
\text { pre- } \\
\text { ference } \\
\end{array}$ & $\begin{array}{l}\text { Weig- } \\
\text { hted } \\
\text { score } \\
\text { of } 1^{\text {st }} \\
\text { pre- } \\
\text { ference } \\
\end{array}$ & $\begin{array}{l}\text { No. of } \\
\text { Ent. } \\
\text { opted } \\
\text { for } 2^{\text {nd }} \\
\text { pre- } \\
\text { ference }\end{array}$ & $\begin{array}{l}\text { Weig- } \\
\text { hted } \\
\text { score } \\
\text { of } 2^{\text {nd }} \\
\text { pre- } \\
\text { ference }\end{array}$ & $\begin{array}{c}\text { No. of } \\
\text { Ent. } \\
\text { opted } \\
\text { for } 3^{\text {rd }} \\
\text { pre- } \\
\text { ference }\end{array}$ & 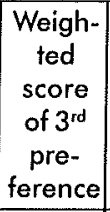 & $\begin{array}{c}\text { Total } \\
\text { weigh- } \\
\text { ted } \\
\text { score }\end{array}$ & Rank \\
\hline $\begin{array}{l}\text { Desire to achieve } \\
\text { something }\end{array}$ & 14 & 42 & 8 & 16 & 27 & 27 & 85 & 111 \\
\hline $\begin{array}{l}\text { Need for } \\
\text { independence }\end{array}$ & 30 & 90 & 15 & 30 & 15 & 15 & 135 & 1 \\
\hline $\begin{array}{l}\text { Desire to get } \\
\text { gainfully occupied }\end{array}$ & 24 & 72 & 11 & 22 & 16 & 1216 & 110 & II \\
\hline To get social prestige & 2 & 6 & 1 & 2 & 25 & 25 & $33^{\circ}$ & IV \\
\hline Success of others & 3 & 9 & 1 & 2 & 10 & 10 & 21 & $V$ \\
\hline $\begin{array}{l}\text { Availability of } \\
\text { Bank Finance }\end{array}$ & & & & & 9 & 9 & 9 & VI \\
\hline $\begin{array}{l}\text { EDP/EAP holders } \\
\text { meeting }\end{array}$ & & & & & 1 & 1 & 1 & VII \\
\hline Any other & 5 & 15 & 2 & 4 & 2 & 2 & 21 & V \\
\hline
\end{tabular}

Source: Survey Dala

It can be seen from Table 5 that the need for independence drove most entrepreneurs to the threshold of entrepreneurship (135 points). The next important factor which influenced entrepreneurs was the desire to get gainfully occupied ( 110 points). The desire to achieve something in life was ranked third (85 points), to get social prestige was ranked fourth (33 points) and the success of others and any other factor included unemployment problems, experience in the same line and initiative taken by the father or husband (in case of women entrepreneurs). Dissatisfaction in previous jobs held, encouragement by friends/relatives, opportunities available, interest in becoming an entrepreneur, availability of raw-materials etc., each ranked fifth (21 points each), the availability of bank finance has rank 6th by only 9 entrepreneurs (that too assigned with the third rank) and EDP/EAP motivated only one entrepreneur to set up a small unit.

\section{Units Promoted by Entrepreneurs}

An attempt was made to study the type of unit floated by the entrepreneurs, form of organisation, location of the units, type of market for the product/service, investment made, turnover, commencement of entrepreneurship and nature of technology used by small entrepreneurs/units. 


\section{Type of Unit}

Commercial banks are assisting the units registered as SSI, tiny units, ancillary units and export-oriented undertakings. Out of the 120 small entrepreneurs surveyed, it was found that 109 entrepreneurs who obtained finance from commercial banks have registered their unit as SSI and the remaining 11 entrepreneurs owned a tiny unit. The remaining two types of units were not found during the field survey.

\section{Form of Organisation}

A majority of the entrepreneurs under study, 82.50 per cent (99 units), had opted for the sole proprietary form of organisation. The remaining 21 were units are formed as partnership firms ( 14 units constituting 11.67 per cent) and joint stock company ( 7 units constituting 5.83 per cent) form of organisation.

Table 6 shows the ownership type of small units in the study area.

Table 6. Form of Organisation of Entrepreneurs

\begin{tabular}{l|c|c}
\hline Type of Ownership & No. of Entrepreneurs & Percentage \\
\hline Sole Ownership & 99 & 82.50 \\
Partnership Firm & 14 & 11.67 \\
Joint Stock Company: & 7 & 5.83 \\
Any other & - & - \\
\hline Total & 120 & 100.00 \\
\hline
\end{tabular}

Source: Survey Dala

\section{Location of the Units}

An ever ready willingness to move from one place to another place and the risk taking ability can be gauged from the choice of location of units by the enirepreneurs. Normally, the location of the units of entrepreneurs is influenced by various factors such as the availability of raw-materials, power supply, proximity to markets, availability of infrastructural facilities etc. A study conducted by Panandikar in Poona city revealed that a woman entrepreneur chose to locate her unit in her house or nearby places because of the dual role she had to play as homemaker and entrepreneur. 
The locations chosen by the entrepreneurs under this study were examined to verify if they preferred a home, rented/leased premises, owned premises or industrial estates. Table 7 shows the location-wise distribution of small entrepreneurs in the study area.

Table 7. Location-wise Distribution of Entrepreneurs

\begin{tabular}{l|c|c}
\hline \multicolumn{1}{c|}{ Location } & No. of Entrepreneurs & Percentage \\
\hline At Home & 15 & 12.50 \\
Owned Premise & 23 & 19.66 \\
Rented/Leased & $1 \dot{14}$ & 11.66 \\
Industrial Estate & 68 & 56.67 \\
\hline Total & 120 & 100.00 \\
\hline
\end{tabular}

Source: Survey Data

Table 7 reveals that a majority of the units, 68 out of 120 units constituting 56.67 per cent, are concentrated in industrial estates followed by 23 units constituting 19.17 per cent of the total in owned premises, 15 units constituting 12.50 per cent at home and the remaining 14 units constituting 11.60 per cent of the total running their units in rented/leased premises.

The above figures show the importance given by commercial banks to the small units located in industrial estates and the role played by them in financing the entrepreneurs. The survey also revealed that some rationalised commercial banks have opened SSI specialised branches in the industrial estates of Peenya and Rajajinagar in Bangalore, Belgaum, Hubli and Mysore etc.

\section{Type of Market}

The market in which the entrepreneurs under study sell their products vary from local markets to the international market. Table 8 indicates the type of market in which the entrepreneurs in the study area operate.

Table 8. Type of Market for Entrepreneurs

\begin{tabular}{l|c|c}
\hline Type of Market & No. of Entrepreneurs & Percentage \\
\hline Local market & 70 & 58.33 \\
Statewide market & 29 & 24.17 \\
National market & 18 & 15.00 \\
International market & 3 & 2.50 \\
\hline Total & 120 & 100.00 \\
\hline
\end{tabular}

Source: Survey Data 
Table 8 reveals that a majority of the small entrepreneurs, 70 (58.33 percent) out of 120 , hold the local market, 29 entrepreneurs (24.17 per cent) are marketing their products throughout the state of Karnataka, 18 entrepreneurs (15 per cent) operate in the national market and the remaining 3 entrepreneurs ( 2.50 per cent) operate in the international market.

\section{Size of the Units}

The success of entrepreneurs is usually judged on the basis of their varying capital over a period of time, turnovers etc. Three different criteria were employed for the study, for measuring the size of the units. They were, quantum of investment, turnover and number of workers employed. Individual criterion analysis is as follows.

\section{A. Quantum of Investment - Initial and Present}

The size of the units can be measured on the basis of capital employed/invested. This aspect is analysed with the below Table 9 by taking the capital employed figures relating to the initial year (i.e., year of commencement of entrepreneurial activities) and the latest year i.e., 31 st March 2000.

Table 9. Investment-wise Distribution of Units

\begin{tabular}{l|c|c|c|c}
\hline \multirow{2}{*}{ Investment Limit } & \multicolumn{2}{|c|}{ At the time of Establishment } & \multicolumn{2}{c}{ At present } \\
\cline { 2 - 5 } & No. of Units & Percentage & No. of Units & Percentage \\
\hline Less than Rs. 1 Lakh & 23 & 19.17 & 9 & 7.50 \\
Rs. 1,00,001 to 3 Lakhs & 34 & 28.33 & 20 & 13.67 \\
Rs. 3,00,001 to 10 Lakhs & 32 & 31.67 & 42 & 35.00 \\
Rs. 10,00,001 to 25 Lakhs & 16 & 13.33 & 27 & 22.50 \\
Rs. 25,00,001 to 60 Lakhs & 6 & 5.00 & 16 & 13.33 \\
Above Rs. 60 Lakhs & - & - & 5 & 4.17 \\
Not Available/Refused & 3 & 2.50 & 1 & 0.83 \\
\hline Total & 120 & 100.00 & 120 & 100.00 \\
\hline
\end{tabular}

Source: Survey Data

Table 9 reveals that out of 120 units, 38 units (31.67 per cent) had investment limit ranging from Rs. $3,00,001$ to Rs. 10 lakhs, 34 units (28.33 per cent) were established with an investment of Rs. 1,00,001 to Rs. 3 lakhs, 23 units (19.17 per cent) with investment less than Rs. 2 lakhs and 16 units (13.33 per cent) with investment ranging from Rs. $10,00,001$ to Rs. 25 lakhs. Only 6 units (5 per cent) had an investment ranging from Rs. $25,00,001$ to Rs. 60 lakhs. 
The above analysis shows that a large majority of the entrepreneurs (79.17 percent) have an investment of less than Rs. 10 lakhs.

Taking into account the total investment made in the latest year under study (i.e., 31 st March 2000) it is found that there has been a sizeable increase in the size of the entrepreneurs' units. It is observed that the number of units with less than Rs. 1 lakh in initial investment have reduced from 19.17 per cent (23 units) of total units af the time of establishment to 7.50 per cent ( 9 units) of total units in the latest year under study. Those units with a total investment ranging from Rs. 1,00,001 to Rs. 3 lakhs are reduced from 28.33 per cent ( 34 units) to 16.67 per cent (20 units) in the latest year under study. At the same time, the number of units with an investment ranging from Rs. 3,00,001 to Rs. 10 lakhs increased from 31.67 per cent ( 38 units) to 35 per cent ( 42 units) at present, registering an increase of 10.52 per cent. Similarly, the number of units with an investment ranging from Rs. $10,00,001$ to Rs. 25 lakhs increased from 16 units initially to 27 units in the latest year under study registering an increase of 166.66 per cent. It is important to note that no unit was started with an initial investment above Rs. 60 lakhs. However, 5 units have investment above Rs. 60 lakhs in the latest year under study. These units have also crossed the investment limit for SSIs prescribed by the government (i.e. Rs. 60 lakhs). This indicates a positive growth in the size of units operated by the small entrepreneurs in the study area.

\section{B. Annual Turnover}

Annual turnover may be taken as one of the criteria for measuring the size and level of entrepreneurial activities. Table 10 indicates the annual turnover of sample units under study.

Table 10. Turnover-wise Distribution of Units

\begin{tabular}{l|c|c}
\hline Annual Turnover (In Rs.) & No. of Entrepreneurs & Percentage \\
\hline Less than 1 Lakh & 9 & 7.50 \\
1,00,001 to 5 Lakhs & 29 & 24.16 \\
5,00,001 to 10 Lakhs & 19 & 15.83 \\
10,00,001 to 25 Lakhs & 29 & 24.17 \\
25,00,001 to 1 Crore & 14 & 11.67 \\
Above 1 Crore & 6 & 5.00 \\
Not available/Refused to give & 14 & 11.67 \\
Closed the Unit & - & - \\
\hline Total & 120 & 100.00 \\
\hline
\end{tabular}

Source: Survey Data 
It may be observed from Table 10 that 29 of the entrepreneurs are in the sales turnover range of Rs. 1,00,001 to Rs. 5 lakhs and Rs. 10,00,001 to Rs, 25 lakhs. In the case of 15.83 per cent entrepreneurs (19 entrepreneurs) the turnover was between Rs. 5,00,001 and Rs. 10 lakhs and between Rs. 25,00,001 and Rs. 1 crore in the case of 11.67 per cent ( 14 units) of the total units. The turnover of 9 units ( 7.50 percent) was less than Rs. 1 lakh and that of 6 units was above Rs. 1 crore. 14 entrepreneurs refused to give the details or opined that the data is not available.

The above figures depict that a large majority of entrepreneurs, 71.66 per cent, are in the sales turnover range of less than Rs. 25 lakhs. Thus the level of the entrepreneurial activities can be considered as small.

\section{Size of Employment}

The employee strength or labour force can be taken as a criterion to measure the size of the units. Table 11 shows the employee strength of the units assisted by commercial banks.

Table 11. Size of Employment

\begin{tabular}{c|c|c}
\hline Number of Employees & No. of Units & Percentage \\
\hline No Employees & 4 & 3.33 \\
One & 3 & 2.50 \\
$2-10$ & 61 & 50.84 \\
$11-25$, & 46 & 38.33 \\
$26-50$ & 6 & 5.00 \\
$51-100$ & - & - \\
Above 100 & - & - \\
\hline Total & 120 & 100.00 \\
\hline
\end{tabular}

Source: Survey Data

Table 11 reveals that there were no employees in 4 units constituting 3.33 per cent of the sample size. These units are managed by the entrepreneurs themselves. 2.50 percent of the units ( 3 units) had only one employee, 50.84 per cent ( 61 units) had 2. 10 employees, 38.33 percent ( 46 units) had $11-25$ employees and 6 units (5 per cent) had 26-50 employees. These figures depict that a significant number of entrepreneurs are running their units with a labour force. 


\section{Commencement of Entrepreneurship}

In the course of establishing a unit, the entrepreneur has to perform several preliminary functions such as finding a suitable site for establishing the unit, completing various statutory requirements, hiring labourers, raising capital and so on. The entrepreneurs under study were asked to indicate whether the unit was established by themselves or inherited from family members or an existing (good or sick) unit was taken over by them. The object was to see the first generation entrepreneurs financially motivated by commercial banks. Table 12 shows the details about the commencement of entrepreneurial activities.

\section{Table 12. Commencement of Small Industrial Unit}

\begin{tabular}{l|c|c}
\hline Commenced by whom? & No. of Entrepreneurs & Percentage \\
\hline Established by the Entrepreneur & 109 & 90.83 \\
Inherited from father/husband & 9 & 7.50 \\
Taken over a good/sick unit & 2 & 1.67 \\
\hline Total & 120 & 100.00 \\
\hline
\end{tabular}

Source: Survey Data

A study of persons responsible for the establishment of the unit indicates that 90.83 per cent (109 entrepreneurs) of the total entrepreneurs established the unit on their own and 7.50 percent of the total units (9 units) were inherited from father/husband and only 2 units (1.67 per cent) were taken over (good or sick) units.

\section{Nature of Technology}

A study into the nature of technology used by the entrepreneurs is made to see the influence of globalisation on the SSI units, innovative nature of entrepreneurs and technology advancement made by them. Table 13 shows the same.

Table 13. Nature of Technology used by Small Units

\begin{tabular}{c|c|c}
\hline Nature of Technology & No. of Entrepreneurs & Percentage \\
\hline Indigenous & 113 & 94.17 \\
\hline Foreign & 7 & 5.83 \\
\hline Total & 120 & 100.00 \\
\hline
\end{tabular}

Source: Survey Data 
Table 13 reveals that 94.17 per cent of the units (133 units) are running with indigenous technology and only 5.83 per cent of the total units (7 units) are using foreign technology. Thus, a very limited number of units are employing foreign technology to run their units. However, the usage of Indian Technology by an overwhelming majority of entrepreneurs cannot be looked or considered as the backwardness of these units.

\section{Performance of Entrepreneurs}

The performance of the entrepreneurs under study is analysed by taking into account the changes introduced by the entrepreneurs, return on investments, profits reinvested into business, influence of education, family background and on category of their performance.

\section{Changes Introduced by Entrepreneurs}

A study regarding changes introduced by the entrepreneurs was made to see the innovative character of entrepreneurs. Peter Drucker defines an entrepreneur as one who always searches for change, responds to it and exploits it in an opportunity. He aptly observed that "Innovation is the specific tool of entrepreneurs, the means by which they exploit change as an opportunity for a different business or a different service. It is capable of being presented as a discipline, capable of being learned and practised. Entrepreneurs need to search purposefully for the source of innovation and the changes in their symptoms that indicate opportunities for successful innovation. And they need to know and to apply the principles of successful innovation." Entrepreneurs in the present study were asked to indicate the changes made by them. The change may take the form of the addition of a new product or service, improvement of the existing product or service, expansion of the unit, installation of modern machinery and establishment of a new unit. Table 14 indicates the type of changes introduced by entrepreneurs. 
Table 14. Changes introduced by Entrepreneurs

\begin{tabular}{l|c|c}
\hline Type of change introduced & No. of Entrepreneurs & $\begin{array}{c}\text { Percentage to Total } \\
\text { i.e., 120 }\end{array}$ \\
\hline Addition of new product & 45 & 37.50 \\
Improvement of existing product & 86 & 71.67 \\
Expansion of unit & 23 & 19.17 \\
Installation of modern machinery & 18 & 15 \\
Establishment of new unit & 18 & 15 \\
No Changes & 9 & 7.50 \\
Closed the unit & - & - \\
\hline Total & 199 & 165.84 \\
\hline
\end{tabular}

Note: Total exceeds 120 and 100 percent due to multiple answers

Source: Survey Data

It can be seen from Table 14 that 92.50 per cent (111 entrepreneurs) of the total had introduced one or more types of the above mentioned changes and 9 entrepreneurs ( 7.5 per cent) had made no changes in their activities after the establishment of the unit. Out of the 111 entrepreneurs that introduced single or multiple changes, 86 entrepreneurs (71.67 per cent) had improved the quality of their products, 45 entrepreneurs $(37.5 \%)$ had added a new product to their venture, 23 entrepreneurs (19.17\%) had expanded their units and 18 each ( 15 per cent each) had installed modern machinery in their units and established a new unit. These figures show the innovative nature of entrepreneurs in the study area.

\section{Return on Investment}

The performance of an entrepreneur can be measured on the basis of the return on capital employed. The entrepreneurs were asked to indicate the average annual returns earned by their units. Table 15 shows the average annual return range on investment. 
Table 15. Return on Investment

\begin{tabular}{l|c|c}
\hline Range of Average Annual Profit Earned & No. of Entrepreneurs & Percentage \\
\hline $6-10$ percent & 35 & 29.17 \\
$11-15$ & 24 & 20.00 \\
$16-20$ & 14 & 11.67 \\
$21-25$ & 24 & 20.00 \\
\hline Total & 97 & 80.84 \\
\hline No profit and no loss & 4 & 3.33 \\
Loss & 6 & 5.00 \\
Not available/ Refused to give & 13 & 10.83 \\
\hline Total & 120 & 100.00 \\
\hline
\end{tabular}

Source: Survey Data

Table 15 shows that around $80.84 \%$ of the entrepreneurs ( 97 out of 120 entrepreneurs) reported that their units had earned profits. Among these 35 entrepreneurs had earned an average annual return of $6-10 \%$ on their investments, 24 entrepreneurs each earned returns ranging from $11-15 \%$ and $21-25 \%$ and 14 entrepreneurs in between $16-20 \%$ return on their investments. Thus, a large majority of bank assisted units were profit yielding ventures.

Further, 4 entrepreneurs (3.33\%) were running their units on a no profit no loss basis, 6 units were running under loss and 14 entrepreneurs have either refused to give or opined that data is not available.

\section{Profit Re-invested in Business}

The entrepreneurs were asked to indicate the average amount of profit which they re-invested into their business. Table 16 shows the same. 
Table 16. Profits Re-invested on Business

\begin{tabular}{l|c|c}
\hline $\begin{array}{l}\text { Percentage of Profit } \\
\text { Pre-invested in Business }\end{array}$ & No. of Entrepreneurs & Percentage \\
\hline Less than $10 \%$ & 28 & 24.14 \\
$11-15 \%$ & 35 & 30.17 \\
Above 20 per cent & 34 & 29.31 \\
\hline Total & 97 & 83.62 \\
\hline Not necessary & - & - \\
To repay the loan & 19 & 16.38 \\
\hline Total & 116 & 100.00 \\
\hline
\end{tabular}

Source: Survey Data

It may be observed from Table 16 that out of the 116 entrepreneurs who are earning profits (including the 13 entrepreneurs who have refused to give the details) 94 entrepreneurs ploughed back the profits earned, to their business. Among them $30.17 \%$ (35 entrepreneurs) re-invested $11-15 \%$ of the profits, $29.39 \%$ (34 entrepreneurs) of the entrepreneurs have ploughed back more than $20 \%$ of the profit earned and $24.14 \%$ (28 entrepreneurs) of the entrepreneurs have ploughed back less than $10 \%$ of the profits earned to their business. 19 entrepreneurs constituting $16.38 \%$ to the total are utilising the profits earned to repay the loan.

\section{Performance vis-à-vis Education}

Education is said to be an important variable, which influences the day-to-day activity of the entrepreneur, from installation to managing the unit and marketing the products or service. Although personal possession of technical knowledge by the entrepreneurs is not essential to effective entrepreneurship, in underdeveloped countries it is likely to be useful to some extent, because good technicians are difficult to find and hard to retain in small scale units. The personal possession of knowledge attains greater importance in case of modern industries. In the absence of education and technical know how the entrepreneurs have to depend on expert consultants for various decisions, which is not always possible and is a costly affair. Many studies conducted in India and abroad have indicated that entrepreneurial development depends on education, work experience and technical know-how. In a study of 95 chemical industries in Baroda, Gujarat, A.S. Rao finds that the entrepreneurs with a technical background perform better when value added or 
average prutits are taken as a criterion. Keeping in view the above, the relationship between education and type of ownership (based on the education background relationship) and education and marketing area (to see the influence of education on marketing area) was made and is presented as below.

\subsection{Education and Type of Ownership}

The levels of education level sometimes influence the choice of form of organisation. To test this, an attempt is made with the help of Table 17.

\section{Table 17. Education and Type of Ownership}

\begin{tabular}{l|c|c|c|c|c|c|c|c}
\hline Education & \multicolumn{6}{|c|}{ Form and Type of Ownership } & \multicolumn{2}{|c}{ Total } \\
\hline & \multicolumn{2}{|c|}{ Sole proprietorship } & \multicolumn{2}{|c|}{ Partnership } & \multicolumn{2}{c|}{$\begin{array}{c}\text { Joint Stock } \\
\text { Company }\end{array}$} & \multicolumn{3}{|c}{} \\
\cline { 2 - 10 } & No. & $\%$ & No. & $\%$ & No. & $\%$ & No. & $\%$ \\
\cline { 2 - 10 } Primary & 27 & 100.00 & - & - & - & - & 27 & 100 \\
Matriculation & 11 & 100.00 & - & - & - & - & 11 & 100 \\
Collegiate & 24 & 80.00 & 3 & - & 3 & 10.00 & 30 & 100 \\
Technology & 37 & 71.15 & 11 & 10.00 & 4 & 7.70 & 52 & 100 \\
\hline Total & 99 & - & 14 & 21.15 & 7 & - & 120 & 100 \\
\hline
\end{tabular}

Source: Survey Data

An analysis of the above Table reveals the tendency among the less educated to restrict their ownership in one's own family on the implicit assumption that it assures smooth running and continuity; since all the 38 entrepreneurs from a lesser education background ( 27 entrepreneurs with primary education and 11 entrepreneurs with education upto matriculation) restricted their ownership type to a family concern. $80 \%$ of the entrepreneurs with collegiate education have formed their units under sole propriety form and $10 \%$ each under partnership and company form of organisation. Similarly $71.15 \%$ of entrepreneurs with technical education formed their units under proprietary form, $21.15 \%$ under partnership firm form and $7.70 \%$ under company form of organisation. These figures show that the tendency to widen the scope of ownership base increases with the level of education. 


\subsection{Education and Marketing Area}

Some amount of education is helping the entrepreneurs in launching their products, capturing the market and widening the market base. With this end in view an attempt is made to see the influence of education on the area of marketing with the help of Table 18.

Table 18. Education and Marketing Area

\begin{tabular}{l|c|c|c|c|c|c|c|c|c|c}
\hline \multirow{2}{*}{ Education } & \multicolumn{10}{|c|}{ Marketing Area } \\
\cline { 2 - 11 } & \multicolumn{2}{|c|}{ Local } & \multicolumn{2}{c|}{ State } & \multicolumn{2}{c|}{ National } & \multicolumn{2}{c}{ International } & \multicolumn{2}{c}{ Total } \\
\hline \multirow{4}{*}{ Primary } & 21 & 77.78 & 3 & 11.11 & 3 & 11.11 & - & - & 27 & 100 \\
Matriculation & 11 & 100 & - & - & - & - & - & - & 11 & 100 \\
Collegiate & 19 & 63.33 & 9 & 30.00 & 2 & 6.67 & - & - & 30 & 100 \\
Technical & 19 & 36.54 & 17 & 32.69 & 13 & 25.00 & 3 & 5.77 & 52 & 100 \\
\hline Total & 70 & & 29 & & 18 & & 3 & & 120 & \\
\hline
\end{tabular}

Source: Survey Data

An analysis of Table 18 reveals that the entrepreneurs with lesser education are concentrated more in the local market than the entrepreneurs with primary education. The share of the entrepreneurs with primary education in the local market is $77.78 \%$, that of matriculation level is $100 \%$, collegiate level is $63.33 \%$ and technical education is only $36.54 \%$. Entrepreneurs, each with Primary, collegiate and technical education are in the state wide and national market. The state wide and national market share of entrepreneurs with collegiate education is $30 \%$ and $6.67 \%$ respectively and technical education is $32.69 \%$ and $25 \%$ respectively. All the 3 entrepreneurs who are operating in the international market are technically qualified.

These figures show that entrepreneurs with higher education in general and technical education in particular are enjoying a wider market base than the other. Thus, education is an influencing factor in the area of marketing.

\section{Performance vis-à-vis Family Background}

The family connection and background is helpful in building an occupational career. It helps the entrepreneur in eliminating or atleast minimising the hurdles in the promotion of the unit, expansion of the unit, making the investment raising the finance and marketing the products. A number of studies indicated that the entrepreneurs from a trade or industrial background continued to dominate the 
entrepreneurial field. A.S. Rao found that the business background of the entrepreneurs has a positive impact, though not significant on the establishment and running of an enterprise. Manohar V. Deshpande found that people with little industrial or commercial background, immersed into entrepreneurship when the suitable conditions were created. In an evaluation of 316 joint stock companies, R.A. Sharma found that business experience in the same or related lines has induced the new and small entrepreneurial class. Sadhak found that entrepreneurs who were formerly traders had better access to financial resources and were less dependent on industrial finance than technocrat/professional entrepreneurs.

Keeping in the view the above, an attempt is made to study the relationship between family background and marketing area and return on investment and profit reinvested into business.

\section{5, I Family Background and Marketing Area}

It is sometimes believed that the background of the entrepreneur influences the marketing area, because the family background proceeds trade connections. This belief is tested with the help of Table 19 below.

Table 19. Family Background and Marketing Area

\begin{tabular}{|c|c|c|c|c|c|c|c|c|c|c|}
\hline \multirow{3}{*}{$\begin{array}{l}\text { Family } \\
\text { Background }\end{array}$} & \multicolumn{8}{|c|}{ Marketing Area } & \multirow{2}{*}{\multicolumn{2}{|c|}{ Total }} \\
\hline & \multicolumn{2}{|c|}{ Local } & \multicolumn{2}{|c|}{ State } & \multicolumn{2}{|c|}{ National } & \multicolumn{2}{|c|}{ International } & & \\
\hline & No. & $\%$ & No. & $\%$ & No. & $\%$ & No. & $\%$ & No. & $\%$ \\
\hline $\begin{array}{l}\text { Trade or Industrial } \\
\text { Background }\end{array}$ & 26 & $\begin{array}{c}54.0 \\
0\end{array}$ & 13 & 26.00 & 8 & 16.00 & 2 & 4.00 & 50 & 100 \\
\hline $\begin{array}{l}\text { Agriculture } \\
\text { Background }\end{array}$ & 17 & $\begin{array}{c}62.9 \\
6\end{array}$ & 8 & 29.63 & 2 & 7.41 & - & - & 27 & 100 \\
\hline $\begin{array}{l}\text { Service/ } \\
\text { Employment }\end{array}$ & 26 & $\begin{array}{c}60.4 \\
7\end{array}$ & 8 & 18.60 & 8 & 18.60 & 1 & 2.33 & 43 & 100 \\
\hline Total & 70 & & 29 & & 18 & & 3 & & 120 & \\
\hline
\end{tabular}

Source: Survey Data

Table 19 reveals that the local, state wide, national and international market share of entrepreneurs from trade or industrial background is $54 \%, 26 \%, 16 \%$ and $4 \%$ respectively. The respective share of entrepreneurs from service or employment background is $60.47 \%$. The entrepreneurs from an agricultural background, not dealing in the local, state wide and national market, is $62.96 \%, 29.63 \%$ and $7.41 \%$. These figures show a lesser concentration of entrepreneurs from the trade 
or industrial background in the local market than the others. They enjoy the lion's share in the international market. The entrepreneurs from the agricultural background stood first in the statewide market and entrepreneurs from service or employment background in the national market. The latter is ranking second in the international market and local market.

These figures show a comparatively wider market base of entrepreneurs from the trade or industrial background followed by the service or employment background and agriculture background.

\subsection{Family Background and Return on Investment}

Return on investment is one of the criteria to assess the performance of entrepreneurs. The influence of a family background on the same is made and presented below.

Table 20. Family Background and Return on Investment

\begin{tabular}{l|c|c|c}
\hline Family Background & $\begin{array}{c}\text { No. of Entrepreneurs } \\
\text { Earning the Profit }\end{array}$ & $\begin{array}{c}\text { Total No. of } \\
\text { Entrepreneurs }\end{array}$ & $\%$ \\
\hline $\begin{array}{l}\text { Trade or Industrial } \\
\text { Background }\end{array}$ & 42 & 50 & 84.00 \\
\hline Agricultural Background & 19 & 27 & 70.37 \\
\hline $\begin{array}{l}\text { Service or Employment } \\
\text { Background }\end{array}$ & 36 & 43 & 83.72 \\
\hline Total & 97 & 120 & \\
\hline
\end{tabular}

Source: Survey Data

It can be seen from Table 20 that $80.83 \%$ of the total entrepreneurs $(97$ out of 120 entrepreneurs) run their units under profit. The background share in the same is $84 \%$ in case of entrepreneurs from a trade or industrial background, $83.72 \%$ in case of entrepreneurs from the service or employment background and $70.37 \%$ in case of entrepreneurs from an agricultural background.

These figures show the better performance of entrepreneurs from a trade or industrial background followed by the service or employment background. The profit earned by entrepreneurs from the agricultural background is below (by 10.46\%) the percentage calculated to total. 


\subsection{Family Background and Profit Re-invested}

An attempt to see the dependency of entrepreneurs from different backgrounds on the profit to meet their business requirements is made and presented with Table 21.

Table 21. Family Background and Profit RE-invested

\begin{tabular}{|c|c|c|c|c|c|c|}
\hline \multirow{2}{*}{$\begin{array}{l}\text { Family } \\
\text { Background } \\
\text { (1) }\end{array}$} & \multicolumn{4}{|c|}{$\begin{array}{c}\text { Percentage of Profit Re-invested and } \\
\text { Number of Entrepreneurs }\end{array}$} & \multirow{2}{*}{\begin{tabular}{|c|}
$\begin{array}{c}\text { No. of } \\
\text { Entrepreneurs }\end{array}$ \\
(3) \\
\end{tabular}} & \multirow{2}{*}{$\begin{array}{c}\% \\
4=2 / 3 \\
(4) \\
\end{array}$} \\
\hline & $\begin{array}{c}\text { Less than } \\
10 \%\end{array}$ & $11-20 \%$ & $\begin{array}{c}\text { Above } \\
20 \%\end{array}$ & $\begin{array}{c}\text { Total } \\
(2)\end{array}$ & & \\
\hline $\begin{array}{l}\text { Trade or Industrial } \\
\text { Background }\end{array}$ & $\begin{array}{c}18 \\
(42.86)\end{array}$ & $\begin{array}{c}14 \\
(33.33)\end{array}$ & $\begin{array}{c}10 \\
(23.81)\end{array}$ & $\begin{array}{c}42 \\
(100)\end{array}$ & 42 & 100 \\
\hline $\begin{array}{l}\text { Agricultural } \\
\text { Background }\end{array}$ & $\begin{array}{c}2 \\
(10.52)\end{array}$ & $\begin{array}{c}8 \\
(42.33)\end{array}$ & $\begin{array}{c}9 \\
(47.37)\end{array}$ & $\begin{array}{c}19 \\
(100)\end{array}$ & 19 & 100 \\
\hline Service/Employment & $\begin{array}{c}8 \\
(22.22) \\
\end{array}$ & $\begin{array}{c}13 \\
(36.11)\end{array}$ & $\begin{array}{c}15 \\
(41.69)\end{array}$ & $\begin{array}{c}36 \\
100\end{array}$ & 36 & 100 \\
\hline Total & $\begin{array}{c}28 \\
(28.87)\end{array}$ & $\begin{array}{c}35 \\
(36.08)\end{array}$ & $\begin{array}{c}34 \\
(35.05)\end{array}$ & $\begin{array}{c}97 \\
(100)\end{array}$ & 97 & \\
\hline
\end{tabular}

Source: Survey Data

Table 21 reveals that all 97 entrepreneurs who earn profits are re-investing a portion into their business. The background cum percentage wise reinvestment comparative study indicates that $42.86 \%$ of the entrepreneurs from trade or industrial background are re-investing less than $10 \%$ of the profits into the business, $33.33 \%$ of the same are re-investing $11-20 \%$ of profit and $23.81 \%$ are re-investing more than $20 \%$ of profit into business. The respective share of the entrepreneurs from an agricultural background in the above three ranges of profit is $10.52 \%, 42.11 \%$ and $47.34 \%$ and the entrepreneurs from the service or employment background is $22.22 \%$, $36.11 \%$ and $41.67 \%$. These figures show the lesser dependency of entrepreneurs from the trade or industrial background on profit to meet their requirements than entrepreneurs from the other two backgrounds.

\section{Performance vis-à-vis Category}

The category/community background of the entrepreneurs is exercising its own influence on their entry into the entrepreneurial field, marketing area, etc. This is because, in our country, the community background is preceded by culture, education/literacy rate, financial base, mobility nature, contacts at the political and official level and other such factors required for successful entrepreneurship. The studies conducted by Oamen, Sharma and Singh and S.G. Bhanushali revealed that the caste/community background had its own impact on the entrepreneurs. 
But Sadhak found that the entrepreneurs emerged from different socio-economic backgrounds. Keeping in view the above, an attempt is made in the ensuing pages to study the influence of category on entry into the entrepreneurial field and marketing area.

\subsection{Category and Year of Establishment of Units}

It would be interesting to examine the time at which the entrepreneurs entered the entrepreneurial field in general and the number of entrants in the period of prenationalisation and post-nationalisation of first phase of banks' nationalisation, i.e., 19'h July 1969. Table 22 shows the same.

Table 22. Category and Year of Establishment of Units

\begin{tabular}{l|c|c|c|c|c|c|c|c|c|c}
\hline \multirow{3}{*}{ Category } & \multicolumn{8}{|c}{ Year of Establishment of Units } \\
\cline { 2 - 11 } & \multicolumn{2}{|c|}{ Before 1970 } & \multicolumn{1}{c}{$1970-80$} & $1980-90$ & \multicolumn{1}{c}{ After 1990} & \multicolumn{2}{|c}{ Total } \\
\cline { 2 - 11 } & No. & $\%$ & No. & $\%$ & No. & $\%$ & No. & $\%$ & No. & $\%$ \\
\hline SC/ST & - & - & - & - & - & 30.00 & 7 & 100.00 & 7 & 100 \\
Women & - & - & - & - & 3 & 33.33 & 7 & 70.00 & 10 & 100 \\
Minority & - & - & - & - & 2 & 26.32 & 4 & 66.67 & 6 & 100 \\
BCM & - & - & - & - & 5 & 21.92 & 19 & 73.68 & 24 & 100 \\
General & - & - & 14 & 19.18 & 16 & & 43 & 58.90 & 73 & 100 \\
\hline Total & - & & 14 & & 26 & & 80 & & 120 & \\
\hline
\end{tabular}

Source: Survey Data

It can be seen from Table 22 that $66.67 \%$ of the sample respondents had entered into the entrepreneurial field only after 1990,21.67\% entrepreneurs in between $1980-90$ and $11.66 \%$ entrepreneurs in between 1970-80. No entrepreneur had set up the unit prior to 1970 i.e. before the first phase of nationalisation of commercial banks, with the financial assistance of private sector banks. This shows the importance given by the nationalized commercial banks to the small scale industrial sector in consonance with the purpose of nationalisation of banks. However, even after bank nationalisation, the weaker sectors of the society ie., SC/ST, women and minority entrepreneurs failed to get the bank's assistance or establish industrial units in the early decades of nationalisation. This is evident from the fact that all the SC/ST entrepreneurs established units with the financial assistance of commercial 
banks only after 1990.3 out of 10 women entrepreneurs (30\%), 2 out of 6 minority entrepreneurs (33.33\%), and 5 out of 24 BCM category entrepreneurs (20.83\%) entered into the entrepreneurial field in between 1980-90 and the rest (in each category) of the entrepreneurs after 1990. But 14 out of 73 general category entrepreneurs (19.18\%) entered the entrepreneurial field with the financial assistance of banks in the early period, at nationalisation itself i.e., 1970-80.

Therefore, it can be concluded that the general category entrepreneurs are the early adopters/chasers of the entrepreneurial field than the others. Thus, the category of entrepreneurs has its own influence on the time of their entry in to the industrial field in the study area.

\subsection{Category and Marketing Area}

After entering the industrial field, the entrepreneur will chase the market and expand his market horizon. This is influenced by the financial base, contacts at different levels, mobile nature, intelligence (both born and self-acquired), communication skill and category. Here, an attempt to study the relationship between the category and marketing area is made with Table 23.

Table 23. Category and Marketing Area

\begin{tabular}{|c|c|c|c|c|c|c|c|c|c|c|}
\hline \multirow{3}{*}{$\begin{array}{l}\text { Family } \\
\text { Background }\end{array}$} & \multicolumn{8}{|c|}{ Marketing Area } & \multirow{2}{*}{\multicolumn{2}{|c|}{ Total }} \\
\hline & \multicolumn{2}{|c|}{ Local } & \multicolumn{2}{|c|}{ State } & \multicolumn{2}{|c|}{ National } & \multicolumn{2}{|c|}{ International } & & \\
\hline & No. & $\%$ & No. & $\%$ & No. & $\%$ & No. & $\%$ & No. & $\%$ \\
\hline $\mathrm{SC} / \mathrm{ST}$ & 7 & 100.00 & - & - & - & - & - & - & 7 & 100 \\
\hline Women & 4 & 40.00 & 3 & 30.00 & 3 & 30.00 & - & - & 10 & 100 \\
\hline Minority & 6 & 100.00 & - & - & - & $\cdots$ & - & 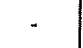 & 6 & 100 \\
\hline $\mathrm{BCM}$ & 17 & 70.83 & 5 & 20.83 & 2 & 8.34 & - & - & 24 & 100 \\
\hline General & 36 & 49.31 & 21 & 28.74 & 13 & 17.81 & 3 & 4.1 & 73 & 100 \\
\hline Total & 70 & & 29 & & 18 & & 3 & & 120 & \\
\hline
\end{tabular}

Source: Survey Data 
It can be seen from Table 23 that all the 7 SC/ST entrepreneurs and 6 minority entrepreneurs are marketing their products locally. The share of women entrepreneurs in the local market is $40 \%$ (4 out of 10 entrepreneurs), BCM entrepreneurs is $70.83 \%$ (17 out of 24 entrepreneurs) and general category entrepreneurs is $49.31 \%$ (36 out of 73 entrepreneurs). The state wide and national market share of women entrepreneurs is 30 per cent each. BCM category entrepreneurs is $20.83 \%$ and $8.34 \%$ respectively and general category entrepreneurs is $28.77 \%$ and $17.81 \%$ respectively. It is important to note that all the 3 entrepreneurs dealing in the international market belong to the general category. Even the 3 women entrepreneurs who are dealing in the state wide and national market are belong to the general category, as the survey reveals.

Thus, it can be concluded that the category backing the entrepreneurs has its own influence on the market base of the entrepreneurs.

\section{Problems of Entrepreneurs}

In the course of managing a small scale unit, an entrepreneur has to face several setbacks and certain problems. An attempt to study the problems faced by the entrepreneurs in the study area was made because an entrepreneur cannot be treated in isolation. He has to be viewed as one constantly interacting with the business sub-system promoted/created by him and this sub-system is a part of a wider socio-economic system. The field survey recognised the following problems faced by the entrepreneurs.

\section{Supply of Raw-materials}

The timely supply of raw-materials will ensure the growth of an entrepreneur. The cost of the product depends on the availability of raw-materials at a reasonable rate. The government has made several arrangements to supply raw-materials to small scale industries. For example, priority has been fixed to supply raw-materials to these units. But in reality it is not so. The entrepreneurs will either get the rawmaterials in timen or is what they get up to the mark. Besides this, transportation problems, strikes, bundhs, floods, famines and other natural havocks also affect the supply of raw-materials.

\section{Marketing Problems}

This is another big problem faced by entrepreneurs. There is no marketing organisation which can ensure the quick and prompt marketing of goods produced by these small entrepreneurs. The role of the Karnataka State Small Industries 
Marketing Corporation Ltd. (KSIMC) in this direction has not been praiseworthy. Marketing is the backbone of small units. Small entrepreneurs are not in a position to popularise and advertise their brand names, since they are not capable of meeting these expenses and canot afford the luxury of expensive advertisements.

\section{Financial Problems}

Financial problems (both term loans and working capital) Are major problems faced by entrepreneurs. Most units which are ancillary to other large industries do not receive timely payments from mother units for their supply. The instances of limiting activity due to the non-availability or insufficient availability of working capital are commion among the small scale units.

\section{Rigid Government Rules}

Entrepreneurs have to approach many offices to get their licences, finance, subsidies, concessions, power supply and fulfil other such statutory requirements. Corrupt practices, cumbersome/rigid and complicated official procedures, red-tapism/undue delays in giving services, lack of guidance etc., are major obstacles faced by the entrepreneurs dealing with government procedures.

\section{Labour Problem}

Small entrepreneurs face problems in the of supply of skilled labour and a high labour turnover rate.

\section{Lack of Power}

The non-availability of sufficient power and interruption in power supply are major problems faced by small scale units in recent years.

\section{Poor Co-ordination}

The co-ordination between lending institutions and government departments is not available in an integrated manner. This causes delays in getting services from other government departments and finance from commercial banks. In a study of selected Asian countries, the Management Development Institution, New Delhi has found that the major problem faced by most Asian countries is the lack of co-ordination of instifutional activities for the development of small scale industries.

\section{Management}

Most diagnostic studies reveal that the cause of sickness in small units is due to the lack of managerial skills and capabilities. Most entrepreneurs are not professionals 
and do not have any sort of training for acquiring managerial skills. The following factors are responsible for sickness in small scale industries:

1. Bad or incompetent management.

2. Lack of adequate finance and working capital.

3. Corrupt practices such as surreptitious removal of assets charged to the banks, diversion/siphoning-off of funds, extravagant expenditure, under invoicing of sales, over-invoicing of purchases etc.

4. It has been observed that in some cases, while the unit has gone sick, promoters have prospered. They consistently look to public sector banks and institutions for soft loans, concessions and sacrifices. Even when a unit turns sick, the promoters continue to live a life of ostentatrousness and extravagance. They also do not furnish the desired information to the banks.

\section{Other Problems}

Besides the above, small entrepreneurs are facing a problem in the lack of proper guidance or the identification of investment opportunity, lack of training facilities in management, production and marketing including advertising and packing, nonavailability of suitable land, sheds in industrial estates and other infrastructural support for the setting up of small units, untimely disbursal of loans and subsidy etc.

The present study makes an attempt to throw light on the problems faced by small entrepreneurs. Table 24 presents the same.

Table 24. General Problems faced by Small Units/Entrepreneurs

\begin{tabular}{l|c|c}
\hline Nature/type of problem & No. of Entrepreneurs & $\begin{array}{c}\text { Percentage to total } \\
\text { i.e., 120 }\end{array}$ \\
\hline Scarcity of Raw-materials & 12 & 10.00 \\
Lack of Power & 74 & 61.67 \\
Transportation Problems & 3 & 2.50 \\
Rigid Government Rules & 38 & 31.67 \\
Financial Problems & 64 & 53.33 \\
Marketing Problems & 55 & 45.83 \\
Labour Problems & 33 & 27.50 \\
Any other & 13 & 10.83 \\
\hline Total & 292 & 243.33 \\
\hline
\end{tabular}

Note: Total exceeds 120 and 100 percent due to multiple answers/problems Source: Survey Data 
The entrepreneurs under the study were asked to indicate the general problems faced by the small entrepreneur. A big number of (61.67\%) entrepreneurs faced problems due to the lack of adequate power. They complained that disruptions in power supply often led to idleness. $53.33 \%$ of the entrepreneurs opined that they are facing financial problems (either term loans or working capital or both), $45.83 \%$ are facing the problem of marketing and $31.67 \%$ of the entrepreneurs under the study reported that they had problems of complying with the various rules and regulations of the government. Some of the entrepreneurs $(27.50 \%)$ experiencing labour problems complained of the difficulty of small units in hiring skilled labour. Small units cannot afford to hire skilled labour and unskilled workers usually leave for better paying jobs, after obtaining some experience, forcing the small entrepreneurs to hire unskilled workers again, only to have the process repeat itself.

Only $10 \%$ of the entrepreneurs reported that their units faced scarcity of raw-materials and $2.5 \%$ of the entrepreneurs have encountered the problem of transportation. According to some entrepreneurs, the transportation problem arises due to the smallness in the scale of operation. The other problems experienced by $10.83 \%$ entrepreneurs include difficulty in obtaining technical know-how for their units, maintenance of quality etc.

\section{References}

1. Alexander P.C., Industrial estates in India, Bombay: Asia Publishing House, 1963.

2. Berna, cited in Bisht, Narendra S. and Sharma Pamila K. Entrepreneurship Expectations and Experience, Bombay: Himalaya Publishing House.

3. Bhansuhali S.G., Entrepreneurship Development, Himalaya Publishing House, Bombay, 1987.

4. Desai Aravindrai N, Environment and Entrepreneur, New Delhi: Ashish Publishing House, 1989.

5. Desai Vasanth, Dynamics of Entrepreneurial Development, Bombay: Himalaya Publishing House, 1991

6. Deshpande Manohar U, Entrepreneurship of Small Scale Industry - Concept, Growth, Management, Delhi: Deep and Deep Publications, 1989.

7. Drucker Peter F, Innovation and Entrepreneurship, Practice and Principles, New Delhi: Affiliated East-West Press Pvt. Ltd. 1991.

8. Haggen E.E., The Economics of Development, p 219 cited in Vasanth Desai, Entrepreneurship Development, Vol. 1, Himalaya Publishing House, Bombay, 1991.

9. Murthy BEWN, M. Chandrashekar and M. Gangadhar Rao., Entrepreneurial Process and Promises, pp. 56-59, cites in M. Gangadhar Rao (Ed), Entrepreneurship and Entrepreneurship Development, Kanishka Publishing House, Delhi. 
10. Oamen M.A., Small Industry in Indian Economic Growth, S.B. Press Trivandrum, 1972, pp. 171-188 cited in Ajay Lakhanpal, Entrepreneurial Development - an Instifutional Approach, Common Wealth Publication, New Delhi, 1990.

11. Sadhak, The Role of Entrepreneur in Backward Area, Delhi: Daya Publishing House.

12. Schumpeter J.A. The Theory of Economic Development, New York: Oxford University, 1967, cited in Desai Vasanth, Volume - I op.cit. 